Милка В. Николић

Универзитет у Крагујевцу

Филолошко-уметнички факултет

Катедра за српски језик

https://doi.org/10.18485/ai_fonefonosj.2020.ch14

81'38:821.163.41.09 Благојевић Д.

811.163.41'38

\title{
ФОНОСТИЛЕМИ У ПОЕЗИЈИ ДЕСИМИРА БЛАГОЈЕВИЋА
}

Песник Десимир Благојевић (1905-1983) стварао је између два светска рата и у послератном периоду. Циљ овог рада јесте да се у његовој поезији издвоје и опишу фоностилематички поступии и да се размотри њихова стилогеност. Анализа је показала да су заступљени фоностилеми који настају двама поступцима: (1) понављағе - понављају се гласови, групе гласова, слогови, граматички/творбени делови речи, речи, групе речи; (2) мимолошки поступии - обухватају ономатопеју (гласовно опонашање звукова који се условно могу аудитивно перципирати) и фонетски симболизам (гласовно сугерисање појава које није могуће аудитивно перципирати). Општи закључак јесте да фоностилеми доприносе смисаоном нијансирању Благојевићевих песама.

Кључне речи: поезија, песник Десимир Благојевић, језичко-стилски поступак, понављање гласова, гласовни симболизам, стилски ефекат.

\section{milkanik75@gmail.com}

** Овај рад написан је у оквиру пројекта Динамика структура савременог сриског језика (2011-2019), број 178014, који финансира Министарство науке и просвете Републике Србије. 


\section{1. Увод}

Поезија Десимира Благојевића (1905-1983) представља „један од најнетипичнијих резултата у новијем српском стваралаштву" (Лалић 1970: 8). Стварао је између два светска рата и у послератном периоду, дакле, у деценијама које су обележене различитим књижевним покретима: ${ }^{3}$

„Када листамо стране Благојевићевих књига, које су настајале у распону од преко четири деценије, ми ћемо свакако запазити да је Благојевићева поезија пролазила кроз врло различите мене израза - али ћемо запазити и једну константу: та поезија је од почетка до краја била и остала верна својим примарним импулсима вербалне фантазије и музикалности" (Лалић 1970: 10).

Његов стваралачки приступ треба посматрати, с једне стране, у контексту тадашњих песничких токова, а с друге, као паралелни и самосвојни развојни пут:

„Десимир Благојевић не робује утицајима, али их све са пуно мере апсорбује и потчињава једном осећању националне поетике, мелодије, мистике, сна и мита. Романтична по даху, модерна по духу, импресионистичка и фолклорна у изразу, машто-

3 Објавио је следеће песничке збирке: Шапутаға с мостова (1924), Карневал анђела (1930), Долазак међ иврчке (1955), Три кантате (1956), Птице немилице (1958), Време безазлених (1958), Родослов (1961), Сребрни пливач (1969). Књиге Земальска трпеза (1967) и Недоходу у походе (1970) садрже изабране песме. Збирка Иичекиваюе сјаја и добродошлица (1984) објављена је постхумно. У књизи Родослови (2004) приређено је осам целина из рукописне заоставштине. 
вита по мелодијској структури, дескриптивна у дочаравању и наслућујућа у описивању, често надреалистички неконтролисана, слободна и инвентивна, симболичка у осмишљавању слика и доживљаја, ова нам поезија открива пре свега музику и неку светлост мутну и невеселу" (Миљковић 1967: 15).

Ако се са лингвостилистичког аспекта испитује стваралачки поступак Десимира Благојевића, запажа се да фоностилеми представљају стилистичку доминанту. Циљ овог рада јесте да се издвоје и опишу типови фоностилематичких поступака у поезији овог савременог српског песника. У досадашњим разматрањима његове поезије, спроведеним у оквиру науке о књижевности, говори се о „звучним својствима“ његових песама. Очекивано је да ће лингвостилистичка анализа гласовног склопа Благојевићеве поезије показати на који начин гласови учествују у смисаоном обликовању стиха, строфе и песме у целини. Корпус чине збирке Земалска трпеза (1967), Недоходу у походе (1970), Родослови (2004).

\section{2. Приступ проблему}

И поред тога што су песме Десимира Благојевића уврштене у антологијске изборе и што су проучаваоци књижевности и књижевни критичари писали о његовој поезији (в. Вукићевић 2006: 193-206), његово стваралаштво није познато широј пубици. ${ }^{4}$ Један од кључних разлога јесте „сама, превасходно звучно-мелодијска природа Благојевићевих стихова":

4 О новијим погледима на Благојевићеву поезују, в. Божовић 2006; Брадић 2006; Гордић 2006; Крагујевић 2006; Микић 2006; Стојановић Пантовић 2006; Стефановић 2006. 
„Једном речју, онај тип поезије који је неговао Благојевић, строго узев, не може бити широко прихваћен, а камоли популаран и опште познат. Сав у језику, Благојевић је, изгледа 'песник за песнике', неко ко привлачи пажњу других језичких посвећеника" (Пантић 2006: 158).

Начин на који се Благојевић односи према звуковном слоју стиха може се тумачити као одраз: (1) „искустава надреализма”, што подразумева писање по „унутрашњем диктату”; (2) „фолклора било изворног, било ослухнутог у нашем романтизму”, при чему се песник посебно интересовао за бајалице, набрајалице, ређалице, тужбалице, здравице и свадбарске песме (уп. Лалић 1970: 9; Ракитић 2004: 613).

Рукописна заоставштина, која садржи бројне варијанте песама и циклуса, као и пишчеве коментаре о томе шта је преостало да се у појединим текстовима исправи, сведочи да су „брижљиво грађени ритам и инсистирње на рими, односно музици, окупирали креативну имагинацију Десимира Благојевића" (уп. Павковић 2006: 80; Ракитић 2004: 631).

По речима познавалаца, Благојевић је запажао да кључни стваралачки проблем његовог поступка јесте у томе „како звучно усаглашен низ да преточи у ниску асицијативно повезану заједничким именитељима а да не изгуби ритамски код” (Лаковић 2006: 100). Проблем усаглашавања значењског и звуковног слоја песме улази у опсег лингвостилистичких истраживања:

„Његова песничка форма само је на први поглед одвећ лабава; она је функционална у оној мери у којој песник сматра да се ритмом и мелодијом може изразити оно што је неизрециво” (Ракитић 2004: 249). 
Стил поетског дискурса се схвата као „конкретан избор одређених језичких аспеката који је сам по себи нужно семантизован, а то значи да управо ти изабрани аспекти постају предмет перцептивног процеса као извора књижевног значења" (Петковић 1975: 176). Задатак стилистичара јесте да испита принципе на којима почива избор семантизованих језичких поступака у књижевном тексту, као и њихово учешће у естетској структури књижевног дела:

„Примијењена у науци о књижевности, стилистика мора проучавати језик књижевног дјела с обзиром на његову стваралачку улогу и на његово значење у цјелокупној структури дјела” (Лешић 2011: 71)

У науци о књижевности сматра се да стилистичка анализа доприноси проучавању књижевног текста уколико успе да дође до „општег естетичког циља којим је прожето читаво дело" (Велек, Ворен 1974: 218). Лингвистичка истраживања књижевноуметничких текстова долазе до сличног закључка:

„Стил [...] није само креативни модалитет производног процеса, већ и она идеја која тим процесом руководи, која се у њега уграђује, која га каналише и доводи до испуњења у креираној хармонији" (Јовановић 2009: 626).

Стил поетског стваралаштва Десимира Благојевића препознатљив је по фоностилемима - што је предмет интересовања у овом раду.

Као што је познато, фоностилистика изучава (1) фоностилистичко раслојавање језика („групне и индивидуалне стилове изговора"), (2) поетску функцију 
гласова и (3) гласовни симболизам (Катнић Бакаршић 2001: 215). Томе треба додати и прозодијске особине говора (интонација, темпо, ритам и др.) јер тек уз потпору супрасегментног нивоа - гласови стичу смисаону надградњу и осмишљеност (Вулетић 1976: 18). ${ }^{5}$

Стилистички потенцијал гласова, заснован на њиховим физичким својствима, реализује се у контексту, у коме гласови имају одређене контекстуалне вредности. Уколико говорник или писац организује контекст на такав начин да гласови постигну „појачани стилски набој”, онда је у питању интенционална стилска вредност или стилогеност (Вуковић 2000: 72).

У овом раду износимо резултате анализе Благојевићевих фоностилематичних поступака у којима учествују гласови. Ритам, мелодију и уопште супрасегментне елементе остављамо за другу прилку (проучаваоци књижевности бавили су се овим феноменима у Благојевићевој поезији).

\section{3. Резултати анализе}

\section{1. Фоностилематички поступци}

Како је анализа показала, Благојевић се ослањао (1) више на поступак понављања, (2) а мање на поступак мимологије. У складу с тим, размотрићемо две групе фоностилема, у оквиру којих ћемо даље издвојити (под)типове.

5 У уџбеницима стилистике истиче се да је предмет и циљеве боностилистике први пут назначио Н. Ф. Трубецки, издвајајући, поред репрезентативне фонологије, још и апелативну и експресивну фонологију, које чине основу фоностилистичких истраживања (Вуковић 2000: 67; Катнић Бакаршић 2001: 215). 
Фоностилеми настали поступком понављања доминирају у нашем корпусу, при чему су понављања и фреквентна и разноврсна. ${ }^{6}$

Понављања се могу систематизовати према језичком феномену који се понавља: (1) гласови, слогови, групе гласова (које не чине слог у речима у којима се јављају); (2) облички делови речи (граматичка основа, наставак за облик); (3) творбени делови речи (творбена основа, суфикс); (4) речи, групе речи. Додаћемо један синтаксостилем, а то је понављање синтаксичких структура (понављају се модели синтаксичких конструкција), што има утицаја на ритам и када се остварује без понављања речи. ${ }^{7}$ Типологија понављања успоставља се и према томе да ли се поновљене јединице налазе на одређеним или на произвољним местима у стиху; дакле, постоје (1) позиционо условљена и (2) позиционо неусловљена понављања. Ако се понављају речи, онда се зависно од тога да ли се мења облик речи, могу издвојити (1) хомоформна и (2) нехомоформна понављања.

Навешћемо примере фоностилема насталих понављањем гласова, слогова и делова речи (издвојених на флективном или дериватолошком плану):

\section{(1) Ово}

Слово,

- Слово оца, слово сина,

Слово огња, Слово и јасмина,

Слово гласно

из даљина,

6 Уопште о поступцима понављања, в. Ковачевић 1998: 137-157; Ковачевић 2015: 295-310.

7 О стилистичкој функцији лексичких, морфолошких и синтаксичких чинилаца у фоностилематици, в. Прањић 1985. 
Слово часно

из давнина,

Ово

Слово,

Слово оца, слово сина,

Слово сина из низина,

- ово

Слово

и оца и сина,

оца, сина

са висина (Родослови, 169)

(2) У земљи си, у мемли си, у тами си, у чами си...

Ко оболи нек оголи, ког заболи, нек се моли земљи, мемли...

[...]

Уземљи се!

Умемли се!

Усами се!

Уплами се! (Родослови, 314-315)

(3) Сушта тама, преко рама

- сушта тама, и небо пролама, зурле пиште, а црквиште 
иште

пој

- oj

седа влас!

[...]

Жеравице, ластавице,

просините заставице,

заставице

и тавнице!

Жеравице, огњетице,

огњетице и витице,

огањ клице,

огњевице,

жеравице,

жарни лице

и јуноше и девице,

вилорепе и сенице!

Жаром жарни,

душом чарни

жеравице, огњетице!

[...]

Сакатило,

кракатило,

семенце се запатило,

семенце је окатило,

семенце се злопатило

и царство се заклатило,

- заклатило,

преклатило (Родослови, 249-261)

(4) Бургијаши,

безлебаши

- сви у шаши...

Батинаши, 
подрепаши,

- сви урлаши...

И сурлаши,

беземљаши,

- сви тамнаши...

Аминаши, безрепаши

- сви у шаши...

Поравнаши,

таљигаши

- сви у шаши...

Глагољаши

и фрулаши

- сви пријаши... (Родослови, 359-369)

(5) Гласно,

громогласно,

многогласно,

и почасно,

рећи гласно,

сасвим јасно:

да л' је касно,

касно?

Касно, касно,

чу се тада полугласно.

Касно, касно,

гнев ће то злогласно.

Касно, касно,

баш ако је и почасно (Родослови, 532).

Запажа се да писац настоји да у сегментима песама или строфа (ако је песма строфична, што је одлика 
само једног дела нашег корпуса) комбинује понављања гласова, делова речи и целовитих хомоформних речи. Стилогеност се појачава ако писац изненађује читаоца начином на који делове синтаксичког низа пресеца и распоређује у стихове, посебно у случајевима када се чланови зависне синтагме поделе у различите стихове.

Ако се понављају речи, било да су понављања позиционо условљена и хомоформна (први од наредна два одломка), било да су позиционо неусловљена и нехомоформна (други одломак), остварују се и фоностилеми и текстостилеми:

(6) Ви који сте ушли у тмину,

знали то или не;

ви који сте забасали у тмину,

хтели то или не;

ви који сад лутате тмином

срећни због тога или не;

ви који сте једно постали са тмином,

слепи због тога или не,

ви који вичете гласом тмине, безутешни или не;

ви који ћутите ћутањем тмине, очајни или не (Земалькка трпеза, 174).

(7) Преко сићаног, преко стења лијем, и торањ и вал тајно обавијем, протичем, течем од дна до дубина; протичем, течем и лијем, лијем и тањим се у вечерњу голубију сенку саму; лијем са галебом, лијем са голубом, са смоквом што улази у огњену таму; лијем са сваким дланом, са сваким рубом, лијем са висина, 
лијем из дубина

лијем,

и с капима се брбљивим и љубим и бијем,

лијем са маслином, лијем са бором,

плачем са гајем, с гондолом лијем,

па немам куд да се скријем (Земалска трпеза, 153).

У посебну подгрупу уврстићемо Благојевићеве текстове који су инспирисани фолклорним творевинама какве су клетве, басме и сватовске песме:

(8) Помором се поморио,

самог себе затворио,

$$
\begin{aligned}
& \text { ој, Морио, } \\
& \text { ој, Морио! }
\end{aligned}
$$

Од Гомора

од помора

бездан себи отворио,

$$
\begin{aligned}
& \text { ој, Морио, } \\
& \text { ој, Морио! } \\
& \text { (Родослови, 551). }
\end{aligned}
$$

(9) Од урока

чудо срока:

од урока,

од зла ока;

од урочја, тог злоочја

(Родослови, 545).

(10) Што ће паун пауници, што ће голуб голубици,

оj, чокању, чокањчићу,

ој, Драгане, Драганчићу! 
Што ће соко соколици, што ће јаран јараници,
oj, чокању, чокањчићу,
ој, Милане, Миланчићу!
(Родослови, 296)

У фоностилистици незаобилазан је појам еуфоничности, па ћемо се на том феномену посебно задржати. Стилистичка литература даје следеће објашњење:

„Kao što je poznato, eufoničnost fonema je $u$ direktnoj vezi sa artikulacijom. Trubecki daje jednu ljestvicu te veze koja ide od nemarne (slabe), preko prosječne (srednje) i povišene, do afektacije. Naravno, svi ti stupnjevi se u kontekstu bolje primjećuju. $\mathrm{Na}$ eufoniju utiče i niz drugih elemenata: otvorenost, zatvorenost, visina. Savremena istraživanja, a naročito Jakobsonova spektrografska mjerenja, otvorila su put u fonostilističku problematiku. Pa ipak, jasan stav o tom kako i zašto glasovi, odnosno fonemi, djeluju na psihu, emocije i estetsko biće čovjekovo nije dat" (Вуковић 2000: 69-70).

Ефуничност фонеме испољава се у утиску пријатности који изговорена фонема оставља на реципијената (за слушање су пријатнији гласови који се лакше изговарају). Томашевски даје следећу скалу: (1) највиши ступањ еуфоничности имају вокали; (2) иза њих су сонорни гласови (осим гласа $p$ ); (3) затим, звучни фрикативи; (4) па безвучни фрикативи; (5) иза њих су експлозиви; (6) на крају су африкате и глас $p$ (Вуковић 2000: 70).

Благојевићева поезија показује да су гласови најнижег ступња еуфоничности погодни за исказивање негативне лирске атмосфере, на пример, неизвесности и 
страха. У овом случају песник настоји да избором речи омогући да се у стиху појаве и изразито еуфонични гласови (пријатни за слушање), чиме се успоставља равнотежа између гласова различитог нивоа еуфоничности.

Наредна два примера упечатљива су и на лексичком и на звучном плану: у првом доминира симболика црног, у другом белог, а заједничка им је асоцијативна веза са смрћу. Прва песма одсликава стање застрашујуће тајновитости од оног што доноси ирна ноћ, а у другој се наговештава стање ужаса у души жртвеног белог јагњега које чека своју смрт:

(11) Тка ноћ, тка црна пређу црну

не на разбоју но на трну.

Тка ноћ, тка пређу црну, ноћ црна, црна тајна ноћ црна, ноћ на трну, тка пређу, тка бескрајна.

Тка ноћ, ноћ на трну, тка црна и ка̂д смиља; тка ноћ, тка пређу црну:

- пређе се ратосиља. $[\ldots]$

Тка црна, ноћ црно тка, ноћ чеду црном у самоћи, ноћ ноћи, црна гатка: ком доћи, ко ће црној поћи? (Земаљска трпеза, 174).

(12) Бело јагње белим блеком

- белим блеком 
белим јеком

у мртвеник!

На жртвеник!

Бело јагње белим јеком

- белим јеком

белом реком

у мртвеник!

На жртвеник!

$[\ldots]$

Бело јагње белом језом

- белом језом

за трпезом:

у мртвеник!

На жртвеник! (Родослови, 103).

У нашем корпусу мање су заступљени - и у погледу фреквенције и у погледу разноврсности типова - фоностилеми настали мимолошким поступцима, што се може објаснити ограниченим могућностима вербалне мимезе (в. Женет 1885: 87). Пошто се глас остварује као звук, њиме је првенствено могуће опонашати појаве које се звучно манифестују. Међутим, присталице мимолошког схватања односа између језика и стварности, сматрају да је сваки предмет у језику добио „тачно име које му од природе лежи" (Женет 1885: 11), као и да постоје „речи од природе одређене за изражавање неких модалности бића" (Женет 1885: 88).

Унутар групе мимолошких фоностилема издвајамо две подгрупе, према два стилематичка поступка путем којих настају: (1) ономатопеја - схваћена у најужем 
смислу као гласовно опонашање звукова из природе; ${ }^{8}$ (2) фонетски симболизам - гласовно сугерисање појава које се не могу аудитивно перципирати. ${ }^{9}$ Стилистичка функција мимолошких фоностилема јесте да гласовно сугеришу одређене значењске нијансе, што ћемо илустровати примерима.

Наводимо примере ономатопеје као преношења и именовања звукова који постоје у реалности, односно имагинарној (пишчевој) реалности.

Песма Буна и визуелно и аудитивно приказује како се не само народ него и целокупна природа укључује у побуну. Ефекат се појачава понављањем гласова, затим, понављањем предлога од, као и понављањем синтаксичких конструкција које се нижу у координативном низу и тако обликују ритам (који одступа од потпуне правилности, чиме се нарушава аутоматизам перцепције, што додатно доприноси стилогености):

\section{(13) И поче}

- од секире, од брадве, с пијука,

од даха, од маха, од пилећег цијука,

од фруле, од куле, од испражњеног сепета,

од, страха, од вратила, од клепета,

од крви коју точе,

8 Ономатопеја је истраживана: у лингвистици (в. Барчот 2014; Драгићевић 1998; Лазић Коњик 2011); у науци о књижевности (в. Ђурић 2017; Пауновић, Вуловић, Стојановић 2005); у музикологији (в. Петровић 2017). Инспиративно је разматрање ономатопеја и заменица као двају „граничних” принципа у функционисању језика - принципи семантизације и граматикализације (в. Пети 1988). У контрастивним истраживањима посебна пажња посвећена је „глаголима стварања звука” као лексичкој класи (уп. Миливојевић 2016: 27-28).

9 Гласовни симболизам у новије време испитује се са когнитивистичког аспекта (в. Кликовац 2004; Кликовац 2008; Јеротијевић Тишма, Каравесовић 2018). 
од преље, од жеље, од трепета, од птице, од сојке, од девојке,

[...]

Tрапа, mpana, mруn. Трум... Трум...

Ко то гази царски друм?

„Изгубили, брате, ум

украј реке, украј друма”

- крешти сврака млатишума.

Трапа, mpana, трум. Труп... Труп...

Ко то гази царски друм?

„Пун дуката траже ћуп,

украј друма”

- шушну шума.

[...]

И бат, и бат, и шььап, и шльап,

опанака ко санака трап,

и торбе клат за врат, клаи, клаи,

и назувице и гаи, гаи,

[...]

од зубуна до катуна

- буна (Земалька трпеза, 313-329).

Стилогеност ономатопеје биће израженија ако се ономатопејска реч налази у синтаксичком окружењу с којим значењски није спојива. У овим случајевима звуци се карактеришу на необичан начин или се приписују неочекиваним појмовима, при чему се фигуративност појачава јер најчешће настају метафоричне и/или синестезијске конструкције:

(14) да хује крила, да хује врело,

да хује над појатама, код сваког шора,

да хује над храстом, да хује код тора (Родослови, 43). 
(15) где букте, мумлају и развезују се прабића, из корена, из пракорена (Родослови, 45).

(16) и кости жуте, после и ребарца, расеје земљом, распе их у прах

- да од њих куиа дамар, пали дах (Родослови, 57).

Међу примерима фонетског симболизма упечатљива је реч безмерје, која је, како се стиче утисак, посебно погодна за песму у којој се исказује бесконачна празнина смрти - кад се човек „коначно настани у безмерју". Ефекат се појачава гласовним поклапањем са речју иверје и понављањем речи тећи, као и тиме што се као рефрен понавља једна строфа кроз целу песму (то је друга строфа у нашем наредном одломку):

(17) Кад се, коначно, настаниш у безмерју,

Ни осрамоћени гроб ти неће рећи

Како свиралу да нађеш у иверју.

$[\ldots]$

$$
\begin{aligned}
& \text { У безмерју, } \\
& \text { ком притећи, } \\
& \text { шта порећи } \\
& \text { у иверју? }
\end{aligned}
$$

Тећи, тећи, тећи...

(Земалька трпеза, 219).

Наводимо одломак из песме која звучно одсликава јутарње певање једне птице (избором гласова, понављањем, низањем кратких стихова иза којих се појављује дуги стих), што се запажа кад се стихови читају наглас: 
(18) Тај чин,

тај глас,

тај трен

Што убрзава и кад се гине и кад спасава

тај час

несмотрен,

надошла јава,

буктави син!

Из љубави у чежњу, из чежње у љубав:

и расточе га ма био и губав,

тај час

тај трен

тај чин,

буктави син! (Земаљска трпеза, 185).

Фонетски симболизам можемо посматрати као синестезију. Као што је познато, под синестезијом се подразумева „метафоричка замјена осјета једног чула осјетима другог чула у сврху сликовитог изражавања“ (Вуковић 2000: 73).

\section{2. Стилогеност фоностилема}

Песник посебну пажњу посвећује „звучној експресивности", што представља уједно и вредност и слабост његовог стваралачког поступка. Наиме, по оцени проучавалаца, Благојевић није увек успевао да оствари „равнотежу музике и смисла”, као ни да „звучне, ритмичке и мелодијске вредности стихова" усклади са смисаоним. Стиче се утисак да бројна понављања различитог типа отежавају праћење значењских нијанси. У појединим његовим поетским текстовима „значење 
се повлачи иза ритамске експресивности, звуком се 'прекрива' унутрашњи смисао, а значење се 'раствара' у звучном обиљу” (Ракитић 2004: 620).

Благојевић је избегавао строге стиховне и строфичне облике (Ракитић 2004: 621) и инсистирао на монорими (Павковић 2006: 89). У песмама већег обима, поготово онима које су кратког стиха, неопходно је било спречити фрагментаризацију и дезинтеграцију форме.

Ако трагамо за стилогеношћу фоностилема, онда стилску функцију испитујемо у контексту. Анализа је показала да су фоностилеми бројни и разноврсни, а у појединим песмама густо распоређени, и као такви уклапају се у контекст Благојевићеве поезије и имају стилску и естетску вредност:

„Песник је у архитектуру песме уграђивао елементе из различитих времена, различитих стилова, различитих семантика, различитих емотивних и мотивских набоја. Његове песме бивају повремено поприште дијалога лирског и епског, реалног и надреалног, хуморног и трагичног, древног и савременог, паганског и новозаветног, туђег и нашег, прошлог и будућег, сачуваног и заборављеног” (Лаковић 2006: 101).

Уопштавајући резултате анализе, можемо рећи да за стилогеност Благојевићевих фоностилема важи закључак који је у стилистичкој литератури изнет за песму Вече на шкољу Алексе Шантића: ${ }^{10}$

10 Почетак развоја лингвостилистичких идеја бајијевског смера у србистици везује се за прве фоностилистичке анализе Шантићеве песме Вече на шкољу (Ковачевић 2012: 6-12). 
„Велика је уметност покренути овако мале масе звукова и значења да са толиком унутрашњом снагом узбуркају машту и заталасају емоције читаоца са развијеним смислом за поетску реч" (Симић 2000: 2016).

На крају, осврнућемо се на однос између фоностилистичког и графостилистичког плана текста. Благојевићеве песме имају знакове интерпункције, а треба узети у обзир и цртицу која се користи у хифенској метафори, као и црту којом се обележава интонационо издвајање. Графички облик песме, тј. „сечење” говорног низа на стихове, као и интерпункцијски и правописни знаци, од пресудног су значаја за рецитатора или глумца који усмено преноси песму. Дакле, писана форма омогућава примаоцу да естетски доживљај оствари на различите начине - када песму чита у себи и када чита наглас.

\section{4. Закључак}

Лингвостилистичка анализа песама Десимира Благојевића потврдила је да фоностилеми представљају стилистичку доминанту у његовом поетском стваралаштву. Издвајају се две групе гласовних стилема.

(а) Фоностилеми настали поступком понављаға могу се разврстати према различитим критеријумима: (1) према језичком феномену који се понавља (гласови, групе гласова, слогови; облички делови речи; творбени делови речи; речи, групе речи); (2) према критеријуму позиције (позиционо условљена и позиционо неусловљена понављања); (3) ако се понављају речи, применљив је критеријум форме (хомоформна и нехомоформна понављања). 
(6) Фоностилеми настали мимолошким поступцима - настају: (1) гласовним опонашањем звукова који се условно могу аудитивно перципирати (ономатоneja); (2) гласовним сугерисањем појава које није могуће аудитивно перципирати (фонетски симболизам у комбинацији са синестезијом).

Доминација поступака понављања јесте у складу с песниковом посвећеношћу ритму. Гласови који се понављају с одређеном правилношћу могу појачати ритмички утисак. Ритам поезије базира се на понављању различитом од природног ритма прозе јер се одликује вештачком организацијом (уређеношћу), али и одступањима од апсолутне регуларности, тј. превареним очекивањем, што се, такође, јавља у Благојевићевој поезији. Поновљене речи функционишу као текстостилеми и доприносе композиционој интеграцији песама. Тиме се спречава фрагментаризација поетског текста, која се сматра слабом страном његовог стваралачког приступа. Интеграцији поетског текста доприноси и понављање модела синтаксичких конструкција (у контактним или у дистактним стиховима).

Мања заступљеност мимолошких поступака проистиче из ограничених могућности језика на плану вербалне мимезе - а у складу с тим - и из пишчеве умерености у употреби овог типа фоностилема. Наиме, песник је био свестан слабости својих гласовних експеримената, зато се може претпоставити да је одустајао од претераних онеобичавања на овом плану.

Може се закључити да гласовни стилеми у поезији Десимира Благојевића стварају својеврсну динамичку равнотежу између разлагања и обједињавања исказа. Општа стилистичка функција фоностилема јесте да гласовно сугеришу одређене значењске нијансе. 


\section{ИЗВОРИ}

Земалька трпеза: Д. Благојевић, Земалькка трпеза, С. Велмар Јанковић (прир.), Београд: Просвета, 1967.

Недоходу у походе: Д. Благојевић, Недоходу у походе, И. В. Лалић (прир.), Београд: СКЗ, 1970.

Родослови: Д. Благојевић, Родослови, С. Ракитић (прир.), Крагујевац: Народна библиотека „Вук Караџић”, 2004.

\section{ЛИТЕРАТУРА}

Барчот 2014: B. Barčot, Onomatopejski glagoli kao sastavnica $\mathrm{u}$ hrvatskim, ruskim i njemačkim zoonimskim frazemima, u: I. Vidović Bolt (ur.), Životinje u frazeološkom ruhu, Elektronsko izdanje zbornika, Zagreb: Filzofski fakultet, 1-13. http://www.animalisticki-frazemi.eu/images/frazemi/ zbornik_radova/BAR-COT\%20za\%20WEB\%20(1).pdf. Датум преузимања: 23. 12. 2019.

Божовић 2006: Г. Божовић, Девет вечерњих песама, у: М. Демић (ур.), Ход према будућима, Крагујевац: Народна библиотека „Вук Караџић”, 147-155.

Брадић 2006: С. Брадић, Језичко и историјско обиље, у: М.

Демић (ур.), Ход према будућима, Крагујевац: Народна библиотека „Вук Караџић”, 163-168.

Велек, Ворен 1974: R. Velek, O. Voren, Teorija književnosti, Beograd: Nolit.

Вукићевић 2006: Д. Вукићевић, Библиографија Десимира Благојевића, у: М. Демић (ур.), Ход према будућима, Крагујевац: Народна библиотека „Вук Караџић”, 169-206.

Вуковић 2000: N. Vuković, Putevi stilističke ideje, Podgorica:

Univerzitet Crne Gore, Nikšić: Jasen.

Вулетић 1976: B. Vuletić, Fonetika književnosti, Zagreb: Liber.

Драгићевић 1998: Р. Драгићевић, О српско-хрватским ономатопејским именицама с елементом -т- у суфиксу, Јужнословенски филолог, LIV, Београд, 121-130.

Гордић 2006: С. Гордић, Фрагменти о Благојевићу, у: М. Демић (ур.), Ход према будућима, Крагујевац: Народна библиотека „Вук Караџић”, 53-78. 
Ђурић 2017: М. Ђурић, Ономатопеја у токовима модернизације књижевности XX века, Кюижевност и језик, LXIV/3-4, Београд, 355-368.

Женет 1985: G. Genette, Mimologije. Put u Katiliju, Zagreb: GZH. Јеротијевић Тишма, Каравесовић 2018: Д. Јеротијевић Тишма, Д. Каравесовић, Звучи убедљиво? Утицај гласовне структуре на одабир назива бренда код српских студента англистике, у: Д. Бошковић, М. Ковачевић, Н. Бубања (ур.), Брендови у књижевности, језику и уметности, Крагујевац: ФИЛУМ, 139-152.

Јовановић 2009: Ј. Јовановић, Писии и стил, Београд: Друштво за српски језик и књижевност Србије.

Катнић Бакаршић 2001: M. Katnić Bakaršić, Stilistika, Sarajevo:

Naučna i univerzitetska knjiga.

Кликовац 2004: D. Klikovac, Vri, štrklja, klječka: o fonetskom simbolizmu u srpskohrvatskom jeziku, u: D. Klikovac, Metafore u mišljenju i jeziku, Beograd: Biblioteka XX vek, 257-274.

Кликовац 2008: D. Klikovac, Andrićeva Lili Lalauna: jezička igra ili nešto više, u: D. Klikovac, Jezik i moć, Beograd: Biblioteka XX vek, 321-328.

Ковачевић 1998: М. Ковачевић, Стилске фигуре и кюижевни текст, Београд: Требник.

Ковачевић 2012: М. Ковачевић, Лингвостилистика кюижевног текста, Београд: СКЗ.

Ковачевић 2015: М. Ковачевић, Стилистика и граматика стилских фигура, Београд: Јасен.

Крагујевић 2006: Т. Крагујевић, Десимир Благојевић - жрец самоће, у: М. Демић (ур.), Ход према будућима, Крагујевац: Народна библиотека „Вук Караџић”, 11-44.

Лазић Коњик 2011: И. Лазић Коњик, Семантичке и деривацијске карактеристике ономатопејских глагола са значењем човековог постојања, у: В. Ружић, С. Павловић (ур.), Лекси$\kappa a$, ономастика, синтакса, Зборник у част Гордани Вуковић, Нови Сад: Филозофски факуллтет, 319-326.

Лаковић 2006: А. Лаковић, Акустичке и игриве асоцијације Благојевићеве заоставштине, у: М. Демић (ур.), Ход према будћима, Крагујевац: Народна библиотека „Вук Караџић”, 93-113. 
Лалић 1970: И. В. Лалић, Поезија Десимира Благојевића, у: Д. Благојевић, Недоходу у походе, И. В. Лалић (прир.), Београд: СКЗ, 7-19.

Лешић 2011: 3. Лешић, Језик и кюижевно дјело, Београд: Службени гласник.

Микић 2006: Р. Микић, Видилац у тами, у: М. Демић (ур.), Ход према будућима, Крагујевац: Народна библиотека „Вук Караџић”, 45-51.

Миливојевић 2016: N. Milivojević, Konstrukcioni idiomi u engleskom i srpskom jeziku, Novi Sad: Filozofski fakultet.

Миљковић 1976: Б. Миљковић, О поезији Десимира Благојевића, у: Д. Благојевић, Земальска трпеза, С. Велмар Јанковић (прир.), Београд: Просвета, 7-17.

Павковић 2006: В. Павковић, Рима и језичка игра, у: М. Демић (ур.), Ход према будућима, Крагујевац: Народна библиотека „Вук Караџић”, 79-91.

Пантић 2006: М. Пантић, Још једном о звучним својствима Благојевићеве песме, у: М. Демић (ур.), Ход према будућима, Крагујевац: Народна библиотека „Вук Караџић”, 157-162.

Пауновић, Вуловић, Стојановић 2005: Ј. Пауновић, М. Вуловић, Т. Стојановић, Ономатопејске речи у роману Трен 2 Антонија Исаковића, Узданица, II/2, Јагодина, 36-39.

Прањић 1985: K. Pranjić, Iz Matoševe fonostilematike, u: K. Pranjić, Jezik i književno djelo, Beograd: IGRO Nova Prosveta, 62-81.

Пети 1988: M. Peti, Zamjenice i onomatopeje, Rasprave, 14, Zagreb, 139-147.

Петковић 1975: Н. Петковић, Језик у кюижевном делу, Београд: Нолит.

Петровић 2017: М. Петровић, Ономатопејски клик звуци, ехолокација и апсолутни слух, Наслеђе, 38, Крагујевац, 329-341.

Ракитић 2004: С. Ракитић, Орфичко завештање, у: Д. Благојевић, Родослови, С. Ракитић (прир.), Крагујевац: Народна библиотека „Вук Караџић”, 609-649.

Симић 2000: Р. Симић, Стилистика српског језика I, Београд: Научно друштво за неговање и проучавање српског језика. Стефановић 2006: М. Стефановић, Сањано воће, у: М. Демић (ур.), Ход према будућима, Крагујевац: Народна библиотека „Вук Караџић”, 133-146. 
Стојановић Пантовић 2006: Б. Стојановић Пантовић, О тамним сагласјима, у: М. Демић (ур.), Ход према будућима, Крагујевац: Народна библиотека „Вук Караџић”, 115-122.

Milka V. Nikolić

\section{THE METHODS OF VOCAL STYLISTICS IN DESIMIR BLAGOJEVIĆ'S POETRY \\ Summary}

The poet Desimir Blagojević (1905-1983) was writing between the two world wars and in post-war period. His creative approach should be observed, on one hand, in the context of the Serbian poetry from the middle of the 20th century, and on the other hand, as a parallel and self-contained progress path. Even though his poems have been included in in the anthologies and his poetry has been written about, the poet is not known to the wider audience today. According to the words of scholars, the poet noticed himself that the main problem with his creative approach was achieving the consistency between the vocal arrangement, rhythm, and meaning of a lyric text. The mentioned problem is also inspirational for linguistic stylistics. The goal of this paper is to separate and describe the dominant stylistic methods and to discuss their stylistic effect in Desimir Blagojevićs poetry. The analysis has shown that Desimir Blagojević mostly relyed on two types of linguo-stylistic methods: (1) the method of vocal repetition, where separate voices, syllables, or groups of voices which do not make a syllable can repeat; (2) the method of vocal symbolism, which indicates that the vocal group of one word implies its meaning. It can be concluded that vocal repetition and vocal symbolism contribute to shading of meaning in Desimir Blagojević's poetry.

Keywords: poetry, poet Desimir Blagojević, linguo-stylistic method, vocal repetition, vocal symbolism, stylistic effect. 